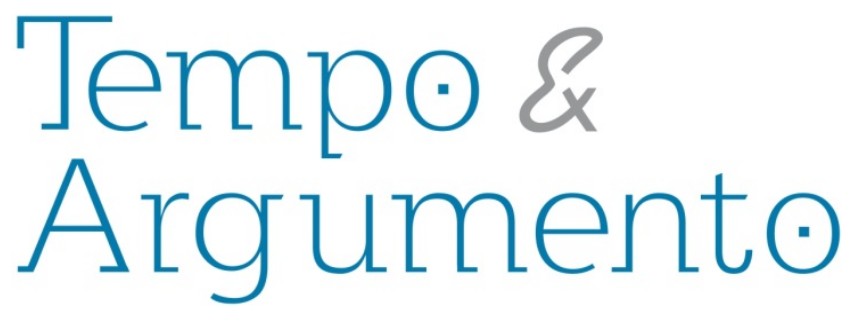

\title{
História e Fotojornalismo: reflexões sobre o conceito e a pesquisa na área
}

\begin{abstract}
Resumo
O objetivo deste artigo é refletir sobre a pesquisa histórica com a fotografia de imprensa e o fotojornalismo nos anos 1970-80 no Brasil a partir de alguns eixos de reflexão: o estatuto da imagem fotográfica, o conceito de fotojornalismo, a construção de uma linguagem fotojornalística própria nas páginas dos veículos, a temporalidade de produção e consumo dos diferentes tipos de fotografia de imprensa, as formas de circulação e de recepção das imagens.
\end{abstract}

Palavras-chave: Fotojornalismo; Fotografia; História e Imprensa.

\author{
Charles Monteiro \\ Doutor em História Social pela Pontifícia \\ Universidade Católica de São Paulo - PUC/SP. Estágio \\ Pós-Doutoral em História Social e Cultural da Arte na \\ Université Paris 1 - Panthéon Sorbonne. Professor do \\ Programa de Pós-Grduação em História da Pontifícia \\ Universidade Católica do \\ Rio Grande do Sul - PPGH-PUC/RS. \\ Brasil \\ monteiro@pucrs.br
}

\section{Para citar este artigo:}

MONTEIRO, Charles. História e Fotojornalismo: reflexões sobre o conceito e a pesquisa na área.

Revista Tempo e Argumento, Florianópolis, v. 8, n. 17, p. 64 - 89. jan./abr. 2016. 


\title{
History and photojournalism: reflections on the concept and research in the area
}

\begin{abstract}
This article aims to think through historical research with press photography and photojournalism in the 1970-80s in Brazil by means of some reflection axes: the photographic image statute, the concept of photojournalism, the construction of a specific photojournalistic language on the pages of the media, the temporality of production and consumption of the various types of press photography, the forms of image circulation and reception.
\end{abstract}

Keywords: Photojournalism; Photography; History and press.

\section{A fotografia e a produção do acontecimento no fotojornalismo}

A fotografia faz parte da comunidade das imagens, mas também se distingue pela técnica de produção (mecânica), reprodutividade (produção de cópias) e ampla capacidade de circulação (imprensa, livro, outdoors etc.) e apropriação por diferentes grupos sociais. Ela realiza um corte na duração, o congelamento de um instante no tempo e um recorte no espaço através do enquadramento. Porém, a fotografia é um "acontecimento" e a inscrição de um sujeito na duração do tempo através da produção da imagem (DURAND, 1998, p. 64). Ela produz um real fotográfico.

Segundo Dubois (1993, p. 61), a fotografia se distingue de outros sistemas de representação como a pintura e o desenho (dos ícones), bem como dos sistemas propriamente linguísticos (dos símbolos) enquanto se aparenta muito com o dos signos como a fumaça (índice do fogo), a sombra (alcance), a poeira (depósito do tempo), a cicatriz (marca de um ferimento) e as ruínas (vestígios de algo que esteve ali). 
Para esse autor, a fotografia não é nem um "espelho do real”, como se pretendia no final do século XIX na imprensa e no senso comum, nem simplesmente a "transformação do real” entendida como redução e distorção desse real, como já foi denunciada a falsa neutralidade da mensagem fotográfica no século XX. A fotografia é um índice, pois guardaria um elo físico com o seu referente.

Rouillé (2009, p. 190) argumenta que a "teoria do índice" defendida por Philippe Dubois, André Bazin, Rosalind Krauss e Roland Barthes, entre outros, promove uma redução no escopo de interpretação da fotografia ao interessar-se mais pelo dispositivo do que propriamente pelas imagens. Em primeiro lugar, essa teoria pretenderia ser uma ontologia, uma abordagem sobre a essência da fotografia, em vez de dar ênfase às imagens e às práticas sociais. Em segundo lugar, porque valorizaria o índice em detrimento do ícone (da semelhança), visando contrapor-se à perspectiva de uma fotografia como espelho do real. Na concepção de Rouillé, porém, o mais interessante seria pensar a "tensão entre o índice e o ícone" como um fator de vitalidade, força e riqueza da fotografia. Em terceiro lugar, privilegia-se o “dispositivo químico" em lugar do “dispositivo ótico", designando o fotograma como "a mais pura expressão da teoria do índice" (ROUILLÉ, 2009, p. 192). Em quarto lugar, procede a uma redução tecnicista ao colocar a atenção no suporte, no microscópico, ao invés do macroscópico das funções sociais, econômicas, culturais e estéticas da fotografia. Em quinto lugar, a redução do tempo fotográfico no instante de captação ao invés da produção do evento e seus usos posteriores. Segundo Soulages (2010, p. 31-35):

A fotografia não é uma restituição do objeto mundo, mas a produção de imagens que interpretam alguns fenômenos visíveis e fotografáveis, de um modo particular existente num espaço e numa história dados: verdadeira revolução em relação à ideologia de [Henry] Luce [Diretor da Revista Life, 1934], que oculta a diversidade de realidades, a sociedade histórica em que são feitas as fotos, os processos de produção e de comunicação dessas fotos e o papel do sujeito que fotografa; são muitos os fatores que condicionam a foto do objeto a ser fotografado. Um acontecimento existe não só em função de seu reconhecimento por uma testemunha, mas principalmente em função de sua constituição como acontecimento por essa testemunha, seja ela fotógrafo ou historiador. Não há acontecimento pré-existente a seu reconhecimento. Não há um objeto-realidade a ser fotografado nem um sujeito que transforma um fenômeno visível em signo de um objeto a ser fotografado. 
Para Rouillé (2009, p. 206) a fotografia não mostra simplesmente ou adere às coisas, mas designa (corpos, coisas, estado de coisas) e exprime (eventos, sentidos). E completa: "É devido à enorme capacidade de designar e exprimir que a fotografia e as mídias conseguem criar o evento a partir do que acontece de mais banal” (Rouillé, 2009, p. 207). Tanto para Rouillé (2009) quanto para Soulages (2010) não se deve dissociar a análise do dispositivo e do médium do estudo do campo fotográfico e de suas transformações. Fotografar seria atualizar um evento que não existiria fora da imagem que o exprime.

Os fotojornalistas trabalham a partir de um sistema simbólico em sua atividade diária lançando mão de um “padrão de verdade”. Segundo Picado (2013, p. 31):

[...] o que define como um 'padrão de verdade' da representação visual, associando-a a um 'princípio de testemunha ocular', cuja origem antecede de muito àquilo que se pode dizer sobre as vocações documentais mais estritas ao meio fotográfico; em verdade as condicionantes deste discurso, em que a imagem evoca (ou até mesmo instaura) acontecimentos, devem ser explicadas não tanto por variáveis associadas a critérios empíricos de sua significação, mas ligados à dramaticidade da representação pictórica.

Tanto o fotógrafo quanto o observador das fotografias lançam mão de suas iconotecas - estoque próprio de imagens dentro do conjunto de imagens socialmente partilhadas em uma determinada época - para produzir sentido e para interpretar uma imagem respectivamente.

\section{O conceito de fotografia de imprensa e fotojornalismo}

Segundo Costa (1992, p. 70), a fotorreportagem constitui-se numa forma jornalística historicamente determinada, que teve suas origens na imprensa alemã no final da década de 20 e inícios dos anos 30. Trata-se de uma narrativa baseada num novo tipo de relacionamento entre texto e imagem, que encontra nas revistas ilustradas o veículo ideal para a sua expressão. Os anos 1950-60 foram a era de ouro do fotojornalismo de revista com Life, Paris Match, L'Express, Der Spigel, Stern, Caras y Caretas e $O$ Cruzeiro, entre tantas outras a circularem na Europa e na América. Período em que se 
restrição dos governos ao acesso ao front de guerra dos jornalistas (SOUSA, 2004a). Os anos 1970 e 80 marcam uma crescente monopolização dos veículos de informação nas mãos de grandes companhias, a industrialização e a homogeneização em nível mundial da linguagem do fotojornalismo dominado por grandes agências de informação (UPI, Reuters, AFP) e de agências de fotografia como Magnum, Rapho, Gamma, Sigma, Sipa etc. (ROUILLÉ, 2009, p. 139-159; SOUSA, 2004a, MOREL, 2006, p. 17-25).

Para Baeza (2001, p. 35-36), em meio à grande diversidade de tipos de imagens veiculadas na imprensa - fotos de receitas, de decoração, de moda etc. - é necessário definir o que se entende como fotografia de imprensa. Este autor sugere começar-se descartando as fotografias publicitárias e todas as demais que apenas "alugam" espaço nas páginas de um periódico, mas que não fazem parte de seu conteúdo editorial. Assim, propõe centrar a análise nas fotografias que a imprensa planifica, produz ou compra e que publica como conteúdo próprio. A este conjunto de imagens pode-se atribuir o termo de "fotografia de imprensa". Esta por sua vez seria constituída por dois grupos principais de imagens: o fotojornalismo e a fotoilustração. O autor compreende que a imagem fotojornalística é aquela produzida ou adquirida pela imprensa com conteúdos editoriais próprios, que estaria relacionada com valores de informação, atualidade e notícia de acontecimentos de relevância social, política, econômica, e que pode ser associada às classificações habituais da imprensa em suas diversas seções (BAEZA, 2001, p. 36).

O termo fotojornalismo designa tanto uma função profissional desenvolvida na imprensa quanto um tipo de imagem utilizada por ela. Nesse sentido, ela se distingue da imagem de publicidade que está presente na imprensa, pois não compartilha os mesmos valores ou ética deontológica de compromisso com a verdade. Nos anos 1940 surgiram os primeiros códigos deontológicos do fotojornalismo nos Estados Unidos e no Canadá. Segundo Lavoie (2010, p. 3), 


\begin{abstract}
"os códigos de deontologia têm por função definir e explicitar as regras e responsabilidades dos membros de uma ordem ou de uma categoria profissional. Eles têm um valor normativo e formalizam as condições a serem respeitadas para manter-se a integridade de uma prática".
\end{abstract}

Também se diferencia da fotoilustração, que seria uma imagem composta de uma fotografia, de fotografias combinadas (colagem ou montagem, digital ou convencional) ou de fotografia associada a outros elementos gráficos que cumpre a função de ilustração de um texto. A fotoilustração é uma imagem vinculada e dependente de um texto, com forte vocação didática, ligada ao jornalismo de serviços: culinária, lazer, moda, esporte etc. (BAEZA, 2001, p. 39).

O fotojornalismo foi desenvolvendo formas de classificação própria para denominar os tipos de imagens que circulam na imprensa. Entre os seus gêneros tradicionais há em seus polos a fotografia de atualidade estrita (predominante nos grandes jornais de circulação diária), determinada pelo imediatismo informativo, e a fotorreportagem, em que a fotografia recebe um tratamento mais interpretativo, sequencial e narrativo (mais comum nas grandes revistas de circulação semanal).

Sousa (2004b, p. 87-108) classifica os tipos de fotografias mais frequentes no fotojornalismo em: spot news, pseudoacontecimentos, photo-illustration, feature-photos, mug-shot, picture stories e fotoensaio. As spot news são fotografias não planeáveis únicas que condensam um acontecimento ou o significado dele, o "furo" ou flagrantes jornalísticos também relacionadas às hot news ou às notícias quentes obtidas no calor dos acontecimentos (incêndios, acidentes de grande proporções, atentados etc.). Pseudoacontecimentos são fotografias semiplaneáveis, como as cerimônias de inauguração, entrega de prêmios, conferências de cúpula etc. Nelas se estabelece uma relação diferente entre fotógrafo e fotografado, pois este, tendo consciência da cobertura da imprensa, pode interferir através de seu posicionamento, pose, gestos etc. na forma de dar-se a ver na imagem. As photo-illustrations são imagens conceituais produzidas "como se fossem uma pintura", frequentemente utilizadas em editoriais de turismo, decoração, culinária, moda, natureza etc. As features photos são fotografias de atualidade que oferecem uma perspectiva singular ou surpreendente flagrada pelo 
veículos de comunicação, que procuram realçar algum traço fisionômico ou de caráter do indivíduo. No Brasil, é muitas vezes chamado de "boneco" com uma conotação pejorativa, pois é considerado um trabalho menor que não exige grande domínio técnico e criatividade do fotógrafo. Já nos retratos ambientes, os indivíduos são retratados em seu lugar de trabalho ou algum outro espaço associado às suas atividades (escritório, biblioteca, laboratório etc.).

As pictures stories são compostas por uma série de imagens que procuram contar uma história ou apresentar as várias facetas de um tema. Elas são um gênero nobre do fotojornalismo, que podemos associar à fotorreportagem. A sua realização requer mais tempo e envolvimento do fotógrafo com o assunto. Normalmente trata-se de um problema social que é tratado em maior profundidade. Elas apresentam geralmente cinco tipos de fotografia: planos gerais de contextualização, planos médios sobre a ação/atividades principais em tela; grandes planos com detalhes significativos do meio, dos sujeitos e das ações; retratos dos sujeitos envolvidos; e uma fotografia de encerramento. No Brasil, os fotojornalistas costumam chamar esse tipo de trabalho publicado na imprensa de "portfólio". Num grande veículo de informação (jornal ou revista), ele fica normalmente a cargo de um fotojornalista experiente e consagrado pela crítica, que através deste tipo de trabalho obtém visibilidade profissional e convites para exposições e projetos independentes. Cabe dizer que boa parte dos fotojornalistas nos anos 1970-80 eram assalariados dos veículos da imprensa, embora a colaboração de fotógrafos freelance fosse frequente e ajudasse a compor, com as imagens compradas de agências de informação, a visualidade fotográfica dos veículos.

O fotoensaio caracteriza-se também por ser uma narrativa em fotografias na qual o fotógrafo / a equipe / o veículo propõe abertamente uma interpretação visual sobre o tema abordado. Existe uma clara distinção entre os defensores da foto única (instante decisivo), que exigiria maior destreza técnica e senso de oportunidade do fotógrafo para sintetizar o acontecimento em uma imagem (à maneira de Cartier-Bresson), dos 
partidários do fotoensaio. Estes defendem um envolvimento maior com os sujeitos e o tema fotografado, que lhes permitiria trabalhar os diversos ângulos do problema com mais tempo e criatividade para produzir uma interpretação em imagens com maior profundidade sobre o assunto.

Nesse sentido, o fotoensaio dialoga com o estilo e os modos de fazer de outro campo da fotografia: o fotodocumentarismo. O fotodocumentarismo compartilha com o fotojornalismo o compromisso com a realidade, porém diferenciar-se-ia desse ao abordar preferencialmente os fenômenos estruturais ao invés da conjuntura noticiosa, distanciando-se desta forma dos prazos de produção mais curtos da imprensa diária. Assim, abre-se também a circuitos mais variados de distribuição, como a galeria, o museu e o livro para a expressão da subjetividade, da criatividade e da poética visual do fotógrafo.

Segundo Ritchin (1988, p. 596), o fotojornalismo "ao estilo estadunidense" teria como objetivo produzir "a foto", o documento-choque para concorrer de forma imediata e superficial com as imagens da televisão. Já a fotorreportagem “à francesa” pressuporia uma aproximação fotográfica dos acontecimentos em sua duração mais lenta visando à afirmação da subjetividade do fotógrafo. A fotorreportagem pode não ser publicada imediatamente após o acontecimento, e assim a imagem deve ter um apelo mais amplo, sugerir uma atmosfera e uma duração mais alargada. O exemplo dado pelo autor é a cobertura fotográfica da coroação do Rei da Inglaterra George VI (1895-1952) por Henri Cartier-Bresson em 1937. Ao invés de aproximar-se do monarca para obter seu retrato, ele fotografa os rostos da multidão pressente nas ruas, acotovelando-se e subindo uns sobre os ombros dos outros para poder melhor ver o acontecimento ${ }^{1}$. Ou seja, o impacto público e a atmosfera do "acontecimento" que estava se produzindo e também sendo produzido pela cobertura da mídia.

Para Sousa (2004a, p. 12), o fotojornalismo no sentido estrito caracterizar-se-ia como uma atividade que visa a "informar, contextualizar, oferecer conhecimento,

\footnotetext{
${ }^{1}$ As fotografias de Henri Cartier-Bresson da coroação podem ser visualizadas no site da Agência Magnum: http://www.magnumphotos.com/C.aspx?VP3=SearchResult\&ALID=2K1HRGRDL32 Acesso em: 8 de fevereiro 2016.
} 
clara, nítida e objetiva um acontecimento voltado ao consumo imediato no jornal/revista para um público amplo. O fotojornalista trabalha com a atualidade, visando mostrar o que está acontecendo no calor da hora e com a "linguagem do instante". A visão do autor sustenta o compromisso do fotógrafo com a verdade e o real.

Porém, fotojornalismo também é um produto cultural no mercado de bens simbólicos. Nesse mercado os veículos tentam fidelizar e ampliar seu público de leitores utilizando diversos recursos editoriais e mercadológicos, entre eles a fotografia de impacto conjugadas às manchetes sensacionalistas nas primeiras páginas dos periódicos.

Para tanto, a fotografia de imprensa frequentemente lança mão de estereótipos para ilustrar matérias e atribuir um sentido facilmente compreensível aos leitores. Para Baeza (2001, p. 36), os redatores-chefes encarregados de selecionar as imagens trazidas à redação pelos fotógrafos sobre uma determinada pauta não buscam conhecer algo que eles não sabiam de antemão, mas ilustrar uma percepção já ancorada no espírito dos leitores e que lhes seria imediatamente observável através da imagem. No ensaio "O instante decisivo" de 1952, o fotógrafo Henri Cartier-Bresson, um dos fundadores da Agência Magnum, já reconhecia este dilema:

A câmera permite fazer uma espécie de crônica visual [do presente]. Nós repórteres fotográficos somos pessoas que fornecem informações para um mundo apressado, oprimido por preocupações, propenso à cacofonia, cheio de seres que precisam a companhia das imagens. $\mathrm{O}$ atalho do pensamento que é a linguagem fotográfica tem um grande poder, mas nós realizamos um julgamento sobre o que vemos e isso implica uma grande responsabilidade. Entre o público e nós, há a impressa, que é o meio de distribuição de nosso pensamento; nós somos os artesãos que entregamos às revistas ilustradas sua matéria-prima (CARTIER-BRESSON, 1981, p. 386).

Joly (2009, p. 160) afirma ser razoável admitir que as fotografias possuam "dominantes" funcionais e que a fotografia de imprensa teria como função principal informar. Segundo a autora, "efetivamente deve 'testemunhar, ilustrar, emocionar, 
bem como ao símbolo, à metáfora e à alegoria. A própria noção de informação seria muito complexa. Ela afirma que:

\begin{abstract}
A noção de 'informação' na imprensa é também particular. Não tem a mesma significação para o profissional que para o pesquisador. Se para o jornalista, para ir mais rápido, 'as infos' são 'as notícias' no sentido tradicional do termo, um pesquisador como Gérard Leblanc pode mostrar que uma informação era geralmente sinônimo de acontecimento, e que um acontecimento era o que rompia com o suposto curso tranquilo da vida: inundações, guerras, acidentes de todo o tipo, e então a noção mesmo de informação era, nesse caso, fortemente ideológica (JOLY, 2009, p. 173).
\end{abstract}

A produção das imagens do fotojornalismo implica o trabalho de diversos profissionais num amplo conjunto de práticas fotográficas, que envolve não apenas o fotógrafo, mas um conjunto de profissionais em uma empresa ou instituição vinculada ao campo da comunicação: diretores de redação, chefe de reportagem, editores de fotografia, redatores, fotógrafos, diagramadores, arquivistas etc. (PROENÇA; MONTEIRO, 2016). Nem sempre é fácil identificar a autoria das imagens fotográficas nas páginas dos periódicos. Nos anos 1950, nas revistas ilustradas, o nome do fotógrafo constava ao lado do nome do repórter. Nos anos 1970, o nome do fotógrafo ou da agência passou a constar na margem da fotografia nas revistas semanais de grande circulação como Veja e Isto É. Porém, nos jornais diários brasileiros a prática de atribuir créditos ao produtor das imagens só se impõe a partir do final dos anos 1970, após uma grande mobilização das associações de fotógrafos (ARFOCs) e dos sindicatos dos jornalistas pela regulamentação e valorização da profissão (COELHO, 2006, 2012; SOUSA JÚNIOR, 2014). Normalmente, os editoriais dos jornais traziam o nome da equipe de jornalismo, destacando os editores e citando os fotógrafos em conjunto. Nas páginas dos jornais, o crédito das imagens era dado apenas à agência. Eventualmente, os nomes dos fotógrafos apareciam na margem de fotografias publicadas na primeira página até o final dos anos 1970. Nesse caso, a 
O fotojornalismo pode ser compreendido como o produto do trabalho de uma equipe de profissionais, mas também pela ação de outros sujeitos sociais que tensionam este campo da comunicação, como: governo, empresários, anunciantes, políticos, censores, etc. Para tanto, é necessário cotejar trabalhos sobre o fotojornalismo com trabalhos sobre História da Imprensa/História da Mídia, no sentido de compreender as trajetórias, as posições, as tensões e as disputas que atravessam o campo do jornalismo.

\section{A fotografia e os diálogos que ela estabelece na página de um periódico}

A fotorreportagem é uma atividade do fotógrafo (contratado ou freelancer) ou equipe de fotógrafos organizados em uma agência (de fotógrafos ou de notícias) e também o produto dessa atividade visível nas páginas de um periódico (jornal ou revista). A sua estrutura envolve um diálogo entre o texto e a imagem no espaço da página dentro do contexto de uma publicação diária, semanal, mensal, etc. A percepção do leitor da(s) fotografia(s) está relacionado a este contexto maior que a(s) envolve: nome do veículo, periodicidade, linha editorial, formato, seções, profissionais e colaboradores eventuais. Cada veículo de comunicação propõe uma leitura do mundo, através de uma tentativa de circunscrever o real e moldar o horizonte de conhecimento dos leitores sobre um determinado conjunto de realidades atuais, do passado e perspectivas sobre o futuro (TAVARES; VAZ, 2005, p. 125-126).

Para Gunthert (2013, p.4), no regime midiático, a visibilidade de uma fotografia depende exclusivamente do lugar que lhe é destinado na hierarquia da informação. Como sistema de seleção e de amplificação da informação, a ferramenta midiática deve organizar suas operações no contexto concorrencial que forma sua ecologia, na ausência da qual produz apenas ruído. O imperativo da hierarquização da informação decorre logicamente desse princípio. No espaço midiático, a cada conteúdo publicado é associado uma indicação de escala, que participa de sua editoração e permite a partir dela gerar sua distribuição. A importância de uma informação se avalia a partir do espaço e da 
localização que ela ocupa na página. Uma informação de um tamanho maior é mais importante que uma de tamanho menor - indicação de natureza relativa e contextual, cuja interpretação repousa sobre a assimilação de um conjunto evolutivo de códigos editoriais. Numerosos fatores, como a reiteração, a notoriedade do autor, o envio de um correspondente, etc., completam esta atribuição de valor por efeito de escala, que se pode por essa razão denominar valor de escala.

Alguns teóricos propõem caminhos para a interpretação das fotografias publicadas nas páginas dos periódicos. Vilches (1997a), ao procurar construir uma metodologia de análise da fotografia inserida na página do periódico, auxilia a compreender as diferentes funções que a fotografia possui, tanto ao nível do conteúdo quanto em termos de expressão formal: enquadramento, diferentes planos, angulação, foco, contrastes visuais, etc. Proposta que é retomada e apropriada por Sousa (2004a, 2004b) e por Mauad (2005). No Brasil, Ana Mauad (1990, 2005, 2008) foi a primeira a elaborar uma proposta metodológica rigorosa no campo da História para a interpretação das imagens na imprensa (fotojornalismo) e sua forma de construir significados sociais. $O$ seu artigo Na mira do olhar (MAUAD, 2005) propõe uma reflexão teórica sobre a fotografia de imprensa e um caminho para a construção de sua interpretação: a escolha dos periódicos, a construção de séries, a elaboração de fichas de interpretação das imagens e a forma de cruzamento dos dados para a compreensão dos padrões visuais e os significados sociopolíticos propostos pela imprensa num determinado contexto. Nesse caso, as fotorreportagens sobre a cidade e a sociedade do Rio de Janeiro nas principais revistas ilustradas brasileiras dos anos 1920 e 1950.

Segundo Gombrich (2002, p. 136), as imagens não são autoexplicativas, pois “a interpretação por parte do autor da imagem deve ser sempre correspondida pela interpretação do observador. Nenhuma imagem conta sua própria história". A interpretação de uma imagem deveria relacionar três variáveis: o código, o texto e o contexto (GOMBRICH, 2002, p. 133). Ou seja, a imagem propriamente dita, os textos que a acompanham e o contexto sociopolítico mais amplo na qual está inserida. Podendo-se ainda acrescentar o diálogo que estas imagens estabelecem com um estoque de imagens herdados do passado e transmitido sobre vários suportes (pintura, escultura, arquitetura, 
A iconografia é a descrição pelo pesquisador da história dos temas específicos ou conceitos tais como são transmitidos através de fontes literárias de época presentes nas imagens. Já a iconologia é a interpretação dos valores 'simbólicos' subjacentes às imagens, que revelam a atitude básica de uma nação, de um período, classe social, crença religiosa ou filosófica - qualificados por uma personalidade e condensados numa obra (Cf. PANOFSKY, 1991, p. 50).

Baeza considera que quanto mais o leitor tiver informações sobre o mundo em geral e sobre o motivo das fotografias em particular, maior será a sua possibilidade de extrair significados e prazer estético das imagens (BAEZA, 2001, p. 174).

O fotojornalismo é a construção de uma narrativa em imagens pela conjugação de fotografias e textos no mosaico da diagramação da página da revista ou do jornal. 0 significado é produzido através do diálogo entre estas duas linguagens, fotografia e textos (manchete, legenda, lead ${ }^{2}$, créditos), numa estrutura complexa e dinâmica. Para Sousa (2004b, p. 66), no fotojornalismo o texto tem várias funções: chamar a atenção para a fotografia, complementar informativamente a fotografia, ancorar o significado da fotografia, abrir um leque de significações possíveis, e, finalmente, comentar ou interpretar a fotografia ou seu conteúdo.

Segundo Lima (1989, p. 31) a relação da fotografia com a escrita se dá em três níveis: fotografia-legenda, fotografia-manchete e fotografia-texto. A legenda é um elemento de ligação entre a fotografia e o texto da reportagem, ela tanto pode ampliar quanto restringir os significados de uma imagem. A segunda alternativa é a mais comum na imprensa diária, pois a necessidade de objetividade, clareza e rapidez de informação incitam a reduzir a polissemia e a ambiguidade própria das imagens. Nesse caso, o repórter ou o editor indica ao leitor o que ele deveria ver naquela imagem. Numa

\footnotetext{
${ }^{2}$ Lead ou lide é a frase de abertura de uma composição breve ou o primeiro parágrafo de um artigo mais longo ou ensaio. É uma fórmula utilizada para atrair o leitor sobre o restante da notícia.
} 
fotografia de guerra, por exemplo, em que vemos soldados e tanques, caberia esclarecer ao leitor de que guerra se trata, quem está lutando contra quem e por quê.

Porém, é muito comum que uma imagem possa trazer significados adicionais e até mesmos contrários ao que é proposto na legenda. Para Gurand (1992, p. 58), a legenda deveria ser um convite para o leitor explorar a imagem e descobrir outros significados ou relações menos evidentes ao primeiro olhar. Ou seja, incitar o leitor a ir além da mera constatação do tema abordado na fotografia, procurando decifrar o ponto de vista a partir do qual o fotógrafo está dando a ver aquele acontecimento.

As manchetes, títulos e subtítulos ocupam um lugar de destaque na página do jornal ou da revista e cumprem um papel semelhante às legendas ao proporem uma primeira leitura e significação do evento pelo leitor. Ao observar a página de um periódico, a atenção é atraída pelas manchetes e pelas imagens devido ao espaço privilegiado que elas ocupam no ordenamento e na hierarquia da página em relação a outros elementos. Entre imagem e texto há uma relação de complementariedade e um diálogo na construção dos sentidos e significados que o veículo quer propor ao seu leitor. Às vezes é a imagem que cumpre a função de manchete, tornando-se uma imagemmanchete, que visa capturar a atenção do leitor e cumprir o papel de síntese visual da matéria.

Ela abre uma série de fotografias que exploram diferentes aspectos do evento, construindo uma narrativa visual através da sequência, da alternância de posições, de tamanhos e de formatos das imagens no mosaico da página. Segundo Costa (1992, p. 82), se a princípio parece impor-se o predomínio da fotografia sobre o texto, a sedução da imagem resultaria do "trabalho invisível da edição". No período áureo da fotorreportagem nas revistas ilustradas nos anos 1950, referindo-se a O Cruzeiro, Peregrino (1991, p. 62) afirma que:

As normas de diagramação estão determinadas pela disposição das fotos, que produz o sentido e o significado a partir das diversas associações feitas entre as margens. Operando com golpes e pausas, esta disposição concentra fotos de páginas inteiras, principalmente no começo, meio e fim da reportagem, alternadas com as outras imagens distribuídas em sequencias variadas... 
Para Costa (1992, p. 83), "a sequência fotográfica tenta recompor o movimento e, ao mesmo tempo, realiza uma operação analítica sobre ele (...) na dilatação e adensamento da temporalidade". Se a fotografia é um fragmento, o congelamento de um instante no tempo, a série fotográfica permite compor uma narrativa (seguindo a tradição do cinema, através da alternância de planos, enquadramento, pontos de vistas e sentido da câmera) e explorar certos aspectos e significados do acontecimento. Usualmente a fotorreportagem começa com uma imagem síntese, de tamanho grande (página inteira ou meia página), seguida de uma série de imagens menores que exploram os detalhes do acontecimento através da aproximação e alternância de planos, enquadramentos e sentidos. Usa-se o plano de detalhamento (aproximação de expressões de rostos, de objetos) para dar intensidade e dramaticidade à narrativa, o que permitiria ao leitor/observador ter a impressão que o acontecimento se desenrola sob seus olhos e o convidaria a explorar diferentes aspectos do mesmo.

\section{Enquadramento, planos e composição.}

Segundo Sousa (2004b, p. 67), o enquadramento corresponde ao recorte da realidade visível realizado pelo fotógrafo e representado na fotografia, que se concretiza no plano. Existem quatro tipos de planos principais com diferentes níveis de expressividade fotográfica: plano geral, plano de conjunto, plano médio e grande plano. Os planos gerais são planos abertos que visam contextualizar o acontecimento, mostram a paisagem (urbana ou rural) onde ocorre e os sujeitos (coletividades ou indivíduos) que participam do acontecimento. Os planos de conjunto são um pouco mais fechados e permitem identificar a ação por completo. O plano médio aproxima-se dos sujeitos e dos objetos, corresponde ao 3/4 americano, que se aproximaria de uma "visão objetiva" da realidade. Os grandes planos enfatizam os detalhes e dão grande expressividade e intensidade aos rostos, objetos e ações representadas. A alternância de planos confere dinamicidade, intensidade e até dramaticidade à narrativa visual do evento.

Soma-se a eles a alteração do ângulo de captação das imagens em relação à superfície do solo, que modifica a hierarquia e o significado das imagens. O plano normal é aquele perpendicular ao solo e na altura dos olhos. Ou seja, fotógrafo e fotografado 

desvalorizar o sujeito ou motivo fotografado. Uma criança tenderia a estar numa posição de inferioridade em relação ao olhar do adulto. Lewis Hine (1874-1940), ao fotografar crianças trabalhando em fábricas americanas nos anos 1910, se ajoelhava para fotografálas visando proporcionar ao observador das imagens o mesmo angulo de visão do mundo do olhar de uma criança, mas também evidenciar a escala de tamanho reduzido delas frente às grandes máquinas têxteis nas quais trabalhavam. No plano contrapicado (contreplongée) a imagem é tomada de baixo para cima, tendendo a valorizar o motivo fotografado. Nos regimes fascistas europeus os líderes políticos eram frequentemente fotografados discursando em uma sacada, de uma janela ou em uma tribuna muito acima do nível do chão e dos olhos da multidão, que se reunia "aos seus pés" para ouvi-los. O que implica uma hierarquização positiva do sujeito e a construção de um sentido de superioridade do motivo fotografado em relação ao observador.

A composição é a ordenação ou disposição dos elementos fotografados no espaço da fotografia. Os fotojornalistas tendem a colocar o motivo no centro ou levemente deslocado do eixo central para facilitar ao leitor/observador a identificação do assunto tratado. O motivo no centro da imagem tem a sua importância realçada. A divisão harmônica do retângulo fotográfico, dividido em metades, terços e quartos é uma tradição que remonta ao renascimento e ao classicismo. Este tipo de composição com o enquadramento dos motivos simétricos (coincidindo com a linha do horizonte e o centro da fotografia) cria uma imagem equilibrada e harmônica. Os fotógrafos tendem a utilizar a regra dos terços (dividindo a imagem em terços horizontais e verticais), colocando o motivo principal da foto na seção áurea, onde o tema ganha mais força. Também é possível criar composições desequilibradas produzindo efeitos de dinamismo ao inverter ou usar escalas desproporcionais em lados opostos do retângulo ou espaços vazios entre os elementos fotografados.

Segundo a psicologia da percepção (Gestalt), o observador percebe os distintos elementos presentes numa fotografia como um conjunto, estabelecendo relações entre 
eles no espaço recortado pela fotografia. Ao observar uma pessoa ou objeto frente a uma parede ou conjunto de prédios, o observador estabelece uma relação entre a figura e o fundo. Ou seja, o que está em segundo plano agrega significado ao que aparece em primeiro plano. Por exemplo, um indivíduo parado em frente a uma mansão. A percepção tende a relacionar e associar os dois elementos, pressupondo que ele vive ou possui aquela residência. Os intelectuais se fazem fotografar atrás de uma escrivaninha e em frente às prateleiras de livros de sua biblioteca (estoque de saber, conhecimento de que disporia em suas atividades profissionais, capital intelectual etc.) como elemento de distinção em relação ao leitor comum. As fotos do industrial com seus operários em frente à fábrica no século XIX construiria o significado de riqueza pela propriedade dos meios de produção: homens, prédios, máquinas e produtos. Também existem as fotos dos pequenos agricultores imigrantes sentados em frente às suas casas com o fruto da colheita à sua frente.

O foco é a zona de melhor definição de uma imagem, o motivo privilegiado da fotografia, que é conferido pelo ajuste do tipo de lente, a abertura do obturador e o tempo de exposição nas câmeras analógicas (não-digitais). Podemos ter um indivíduo em foco no primeiro plano e outros fora em segundo plano, assim como o foco pode estar no segundo ou terceiro plano (fundo). O fotógrafo pode aproximar duas pessoas distantes no espaço e dar a ideia de que estão conversando uma com a outra através do foco, da escolha do ângulo da tomada, da abertura e do tipo de lente. Procedimento muito utilizado no fotojornalismo para colocar políticos rivais lado a lado como se estivessem tendo uma conversa reservada.

Há ainda os elementos morfológicos da fotografia analógica que também concorrem para a produção de sentido na fotografia, como: grão, mancha, pontos, linhas, texturas, padrão e cor (SOUSA, 2004b, p. 73-76). A fotografia com grão pequeno pode criar o efeito de realismo (grãos pequenos) e grãos grandes de desagregação. As manchas podem criar sombras e darem um efeito ameaçador ao motivo representado. Uma pessoa pode ser um ponto no espaço, várias formarem uma linha criando efeitos de ordenação do espaço fotográfico. A repetição de elementos (pessoas, árvores, postes, arbustos) no espaço cria linhas, definindo direções e sentidos para o olhar do observador 
dentro do enquadramento fotográfico. Às vezes contrariando o sentido tradicional de leitura da imagem da esquerda para a direita, podendo servir também para construir sentidos de unidade ou de antagonismo entre dois motivos ou sujeitos fotografados. Os padrões são criados pela repetição de um mesmo motivo na imagem que produzem uma ordenação do espaço e do olhar.

O fotógrafo pode criar efeitos de textura ao fotografar rostos e mãos enrugados ou muros limosos para sugerir a passagem do tempo. A cor confere significado a uma imagem. Cores quentes e fortes podem sugerir conflito ou dinamismo, já cores suaves a harmonia e a estabilidade. Pode-se invocar o famoso caso do escurecimento proposital do rosto do jogador e ator negro O. J. Simpson na capa da revista Time (edição de 27 de junho de 1994), durante seu julgamento, para torná-lo mais ameaçador, o que provocou severos questionamentos sobre a posição racial do periódico (MIRZOEFF, 1999, p. 135).

Podem-se criar padrões de verdade lançando mão de "valores comunicacionais que atribuímos aos gestos, à postura corporal, à aparência dos elementos da cena e à expressão fisionômica momentânea dos agentes, assim como a relação que estes elementos podem manter entre si e com o espaço restante" (PICADO, 2013, p. 31).

Para pensar a recepção das imagens, o historiador tem poucos indícios à sua disposição, como cartas de leitores publicadas pelos veículos (sobretudo para as revistas ilustradas) junto ao editorial e os dados sobre o valor de capa e a tiragem dos periódicos (número de exemplares, estimativa do número de leitores), que permitem especular sobre a circulação (abrangência espacial - internacional, nacional, regional ou local) e a penetração social. A reutilização de uma foto em outras fotorreportagens, sua publicação em livro ou exposição em museus/festivais também indica sua capacidade de sintetizar/representar/expressar visualmente um acontecimento ao longo do tempo. Ou seja, a permanência de uma imagem em vários meios e circuitos indica que ela foi capaz de condensar significados sociais ou o imaginário social sobre determinado acontecimento, conjuntura ou processo social. Tal capacidade deve-se geralmente não apenas ao conteúdo da imagem (tema, situação, sujeitos envolvidos), mas também à qualidade estética da imagem (composição, enquadramento, dinâmica de planos, foco, iluminação etc.) além do diálogo desta com uma tradição visual capaz de atualizar e gerar 
Espanhola (1936), de Roberto Capa, e a foto de Nick Ut da menina Kim Phuc nua fugindo do bombardeio de sua vila no Vietnã (1972).

\section{Considerações Finais}

São várias as questões que se devem levar em conta ao se interpretarem imagens do fotojornalismo em periódicos, mas creio que se deva começar pela própria imagem, depois passar à estrutura da página (imagens e textos), em seguida relacioná-la ao conjunto do periódico (imagens e texto de outras seções com os quais ela dialoga), para finalmente considerar o contexto e as estruturas sociais, políticas e econômicas mais amplas envolvidas na sua produção que condicionam a sua recepção social. Assim, privilegia-se a potência da imagem na produção de sentidos e significados sociais sobre o mundo ao invés de subordiná-la ao papel de caixa de ressonância do contexto político, econômico e social.

Como afirma Debray (1994), a imagem tem uma potência que remete às várias camadas de tempo e de experiência de que ela é portadora. A força de uma imagem também está relacionada com a sua capacidade de evocar outras imagens presentes na tradição e no imaginário. Por exemplo, vários autores já se referiram ao apelo à iconografia cristã na forma de composição das imagens de fotojornalistas, como Sebastião Salgado (Cf. STALLABRAS, 1997; MRAZ, 2005).

O fotojornalismo mudou depois dos anos 1980 devido à massificação, à industrialização da notícia e ao apelo recorrente ao sensacionalismo. A vocação documental associada à ideia de realismo e a concepção de aderência do referente à fotografia entraram em declínio. A fotografia passou a ser compreendida como produtora do acontecimento, como uma forma de interpretação, recriação e atualização do real.

Os jornais diários de grande circulação nos anos 1970 não foram espaços para a livre expressão da criatividade, a renovação da linguagem fotográfica e a afirmação da 
figura de autor dos fotógrafos. Nos jornais diários os fotógrafos estão subordinados a uma pauta prévia definida pelo editor, têm pouca autonomia para proporem suas próprias pautas, um tempo exíguo para desenvolver seu trabalho e entregar uma foto na redação, seguidamente as suas imagens são cortadas e reenquadradas para se encaixarem na diagramação da página, além de muitas vezes estarem totalmente subordinadas à narrativa textual. A exceção pode ser feita às revistas semanais como Realidade (1966-1979), que contratava fotógrafos para realizarem fotoensaios, a revistas Veja em seus primeiros anos de funcionamento e, posteriormente, Isto É, que tentavam se diferenciar através de uma abordagem mais crítica e autoral. Foi buscando maior autonomia, para realizar um trabalho mais autoral e obter reconhecimento financeiro, que os fotógrafos criaram as agências de fotógrafos como Focontexto, F4, Angular, Agil e Ponto de Vista, entre outras. Inicialmente elas funcionavam como coletivos de fotógrafos que discutiam a elaboração de pautas e a forma de realizar as coberturas dos acontecimentos, mas também permitia liberdade aos profissionais para que eles pudessem imprimir uma marca pessoal em seu trabalho fotográfico.

Também houve no contexto dos anos 1970 e 80 os jornais chamados de "nanicos", produzidos por sindicatos e cooperativas, que permitiram uma maior liberdade criativa para os fotógrafos. Um exemplo disso foi o Coojornal, editado em Porto Alegre por uma cooperativa de jornalistas entre 1974 e 1983. Por funcionar como uma cooperativa, as pautas e as escolhas das imagens eram fruto de discussão e acordo entre editores, redatores e fotojornalistas.

Ocorre uma mudança no estatuto das imagens fotojornalísticas a partir de sua publicação em livro, exibição em museus, festivais, feiras de fotografia e galerias de arte. De testemunho de um contexto histórico elas passaram a ser objeto de deleite visual, abrem-se outras possibilidades de interpretação das imagens para além de sua vinculação com o acontecimento. Elas passam também a ser avaliadas pelo domínio técnico (luz, enquadramento, abertura, tons, cor etc.) e pelo olhar singular do fotógrafo sobre o assunto abordado, que eventualmente também podem estar relacionados a um comportamento nostálgico frente ao passado.

Um exemplo brasileiro é o trabalho do fotojornalista Evandro Teixeira (1935), que cobriu os bastidores do Golpe Militar, as manifestações estudantis de 1968 no Rio de 
Janeiro e também o processo de abertura política para o Jornal do Brasil. Da página do jornal suas fotografias passaram para o livro Fotojornalismo (TEIXEITRA, 1982) e, depois, para os museus de arte. Observe-se a recente exposição retrospectiva de 2015 celebrando seus 60 anos de profissão no Museu de Arte do Rio de Janeiro (MAR): "Evandro Teixeira a constituição do mundo".

Nesse sentido, pode-se pensar nas Mostra da Galeria da FUNARTE (1979-1980) e nos livros publicado por Orlando Brito (Perfil do Poder, 1981) e Evandro Teixeira (Fotojornalismo, 1982), que conferem um novo estatuto às imagens do fotojornalismo.

As exposições fotográficas, as publicações de catálogos e, especialmente, de fotolivros por editoras independentes foram alternativas para a afirmação do fotógrafo como "autor" (GAËLLE, 2008, p. 113). Essa nova concepção de fotografia de autor abriria espaço para a expressão da subjetividade dos fotojornalistas e para experimentações em alguns jornais diários de grande circulação, como, por exemplo, no jornal Libération (Paris, França) nos anos 1970. No Brasil, estas experiências ocorreriam mais tardiamente, como no trabalho do coletivo Cia de Foto na Folha de São Paulo (Brasil) nos anos 2010.

O que também termina por aproximar o fotojornalismo do campo da arte nos anos 1970 na Europa e 1990 no Brasil como forma de afirmação da subjetividade e de uma linguagem pessoal do fotógrafo frente às crescentes restrições ao exercício criativo da fotografia na maioria dos grandes veículos de imprensa (ROUILLÉ, 2009; POIVERT, 2008). Pode ser observada na seleção das fotografias premiadas na Word Press Photo e no The International Photojournalism Festival of Perpignan - Visa pour l'Image a premiação de fotógrafos que não só abordam temas de grande relevância mundial na atualidade, mas que também trabalhem a dimensão estética das imagens, provocando tanto o questionamento da realidade quanto o deleite visual de seus leitores/observadores ${ }^{3}$. No Brasil, os fotojornalistas em seu ofício cotidiano terminam realizando imagens para a

\footnotetext{
${ }^{3}$ A World Press Photo Foundation visa a promoção do trabalho dos jornalistas visuais com uma gama de atividades e iniciativas que abrangem todo o globo. Fomos criados em 1955, quando um grupo de fotógrafos holandeses organizou um concurso para expor seu trabalho aos colegas de outros países. $\mathrm{O}$ concurso anual desde então tem crescido e tornou-se um dos mais prestigiados prémios em fotojornalismo e multimídia. A exposição é vista por mais de três milhões e meio de pessoas no mundo a cada ano. Texto traduzido do Site: http://www.worldpressphoto.org/about. Ver também o site do Festival Internacional Visa de Fotojornalismo pela Imagem de Perpignan em: http://www.visapourlimage.com/index.do.
} 

(exposições, galerias e fotolivros).

Entretanto, as imagens publicadas na mídia são apenas uma parte ínfima das imagens produzidas pelos fotojornalistas, as demais repousam esquecidas nos arquivos de fotógrafos e das agências para serem eventualmente reutilizadas em uma matéria na imprensa ou em uma exposição retrospectiva do fotógrafo. Poivert (2013) sustenta que a pesquisa sobre fotojornalismo deve incluir as folhas de contato ${ }^{4}$ para pensar a construção de sentidos pelo fotógrafo antes de sua seleção, reenquadramento e associação a um texto (manchete, lead, legenda) pelo editor de fotografia e sua publicação ${ }^{5}$. Mas como o historiador poderia ter acesso para sua pesquisa a essa massa de imagens que não foi publicada e que se encontra em posse dos fotógrafos e das agências de informação sob as leis de copyright?

Para concluir, poder-se-ia perguntar em que medida a História está preparada para pensar e problematizar o enorme acervo de imagens publicadas na imprensa, presente nos bancos de dados de periódicos, nos arquivos pessoais dos fotógrafos, circulando nos blogs e nas redes sociais na internet atualmente. E como preparar o cidadão comum e o futuro professor-pesquisador para interpretar essas imagens dentro de um regime de visualidade marcado pelo digital, pelo virtual, pela promoção do eu (selfie) e a espetacularização do acontecimento em que vivemos?

Estes são temas que os historiadores em diálogo com outros cientistas sociais devem debater, no sentido de compreender a "virada visual" iniciada nos anos 1990 e que estamos vivendo nos dias de hoje (MIRZOEFF, 1999). Cabe aos historiadores pensar sobre o que a "oficina da história" pode fazer e deve buscar em outros campos de saber para responder às demandas sociais de conhecimento atuais sobre a vida cotidiana e para continuar atuando de forma significativa na democratização da sociedade da informação.

\footnotetext{
${ }^{4} \mathrm{O}$ contato é uma prova fotográfica de tamanho reduzido, que é produzida pelo contato direto das tiras de negativo com o papel fotográfico em laboratório, usada para escolher as fotos a serem ampliadas.

${ }^{5}$ Tentou-se aplicar parcialmente esta proposta de trabalho sobre a folha de contato na interpretação da fotorreportagem de fotógrafo Ricardo Chaves para a revista Veja sobre o movimento estudantil em Porto Alegre em 1977 (PROENÇA; MONTEIRO 2016).
} 


\section{Referências}

BAEZA, Pepe. Por una función crítica de la fotografía de prensa. Barcelona: Editorial Gustavo Gili, 2001.

CARTIER-BRESSON, Henri. The decisive moment (1952). In: GOLDBERG, Vicki (Edit.). Photography in print: writings from 1816 to the presente. New York: Simon and Schuster, 1981, p. 384-386.

COELHO, Maria Beatriz . O campo da profissional no Brasil. In: Varia História, Belo Horizonte, v. 22, n. 35: p.79-99, Jan./Jun., 2006.

COELHO, Maria Beatriz. Imagens da nação: brasileiros na fotodocumentação de 1940 até o final do século XX. Belo Horizonte: UFMG, 2012.

COSTA, Helouise. Aprenda a ver as coisas: fotojornalismo e modernidade na revista $\mathrm{O}$ Cruzeiro. 1992, 190 f. Dissertação (Mestrado em Comunicação) - Universidade de São Paulo, Escola de Comunicação e Artes Visuais, São Paulo, 1992.

COSTA, Helouise; BURGI, Sergio (Org.). As origens do fotojornalismo no Brasil: um olhar sobre o Cruzeiro 1940-1960. São Paulo: IMS, 2012.

DEBRAY, Régis. Vida e morte da imagem: uma história do olhar no ocidente. Petrópolis, RJ: Vozes, 1994, p. 21-43.

DUBOIS, Philippe. O ato Fotográfico e outros ensaios. Campinas, SP: Papirus, 1993. FRIZOT, Michel (Ed.). A new history of photography. Köln: Könemann, 1988.

DURAND, Régis. El tiempo de la imagen. Ensayo sobre las condiciones de una historía de las formas fotográficas. Salamanca: Ediciones Universidad de Salamanca, 1998.

GOMBRICH, Ernest Hans. La imagen y el ojo: nuevos estudios sobre la psicología de la representación pictórica. 2a. ed. Madrid: Debate, 2002.

GUNTHER, André. Les ícones du photojournalisme, ou la narration visuelle inavouable. 25/1/2013. p. 1-21. Disponível em: <culturevisuelle.org/ícones/2609>. Acesso: 30 jan. 2013.

GURAND, Milton. Linguagem fotográfica e informação. Rio de Janeiro: Rio Fundo Editora, 1992.

LIMA, Ivan. Fotojornalismo Brasileiro. Realidade e Linguagem. Rio de Janeiro: Fotografia Brasileira, 1989.JOLY, Martine. La imagen fija. Buenos Aires: La Marca, 2003. 
LAVOIE, Vincent. La rectitude photojournalistique : codes de déontologie, éthique et définition morale de l'image de presse. In: POIVERT, Michel. Études photographiques. Paris: Société Française de Photographie, 2010, p. 1-14.

LOUZADA, Silvana. Prata da casa: fotógrafos e fotografia no Rio de Janeiro (1950-1960). Niterói, EDUFF, 2013.

MAUAD, Ana Maria. Sob o signo da imagem: a produção da fotografia e o controle dos códigos de representação social da classe dominante no Rio de Janeiro na primeira metade do século XX, 1990, 570f. Tese (Doutorado em História) - Universidade Federal Fluminense, Programa de Pós-Graduação em História Social. Niterói, 1990.

MAUAD, Ana Maria. Na mira do olhar: um exercício de análise da fotografia nas revistas ilustradas cariocas, na primeira metade do século XX. Anais do Museu Paulista, v.13, n.1, p. 133-174, 2005.

MAUAD, Ana Maria. Poses e flagrantes: ensaios sobre história e fotografia. Niterói/RJ: EdUFF, 2008.

MIRZOEFF, Nicholas. An introduction to visual culture. London: Routledge, 1999.

MONTEIRO, Charles. Imagens sedutoras da modernidade urbana: reflexões sobre a construção de um novo padrão de visualidade urbana nas revistas ilustradas na década de 1950. Revista Brasileira de História, v. 27, p. 159-176, 2007.

MONTEIRO, Charles. El campo de a Fotografía y las imágenes del Brasil em los años 197080: Entre el fotoperiodismo y la fotografía documental. Artelogie. n. 7, abr. 2015.

MOREL, Gaëlle. Le photoreportage d'auteur. L'institution culturelle de la photographie em France depuis les années 1970. Paris: Editions CNRS, 2006.

MOREL, Gaëlle. Esthétique de l'auteur. Signes subjetifs ou retrait documentaire? In: In: MOREL, Gaëlle. (Org.). Photojournalisme et Art contemporain : les derniers tableaux. Paris: Éditions des Archives Contemporaines, 2008. p. 101-113.

MOREL, Gaëlle; GERVAIS, Thierry. 1843-2002: De la prensa ilustrada a los modernos médios de comunicación. In: GUNTHERT, André; POIVERT, Michel. El arte de la fotografia: de las orígenes a la actualidad. Barcelona: Lunwerg, 2009. p. 304-355.

MRAZ, John. Sebastião Salgado: maneiras de ver a América Latina. Studium, n.19, Unicamp, 2005. Disponível em <HTTP://www.studium.iar.unicamp.br/19/01.html $\geq$. Acesso em:16/6/2015.... 
PANOFSKY, Erwin. Iconografia e Iconologia: uma introdução ao estudo do renascimento. In: PANOFSKY, Erwin. . Significado nas artes visuais. São Paulo: Perspectiva, 1991, p. 50.

PEREGRINO, Nadja. “O Cruzeiro”: a revolução da fotorreportagem. Rio de Janeiro: DAZIBAO, 1991.

PICADO, Benjamin. Os regimes do acontecimento na imagem fotográfica. Do "estilo documentário" à "imersão testemunhal", no fotojornalismo e na fotografia documental. In: BRASIL, André; MORETTIN, Eduardo; LISSOVISKY, Mauricio. Visualidades hoje. Brasília: EDUFBA; Salvador: COMPÓS, 2013, p. 15-40.

POIVERT, Michel; GUNTHERT, Andre. L'art de la photographie. Paris: Citadelles \& Mazenod, 2007.

POIVERT, Michel. De l' image imprimée à l'image exposée: La photographie de reportage et le "mythe de l' exposition" In: MOREL, Gaëlle. (Org.). Photojournalisme et Art contemporain : les derniers tableaux. Paris: Éditions des Archives Contemporaines, 2008. p. 87-100.

POIVERT, Michel. Gilles Caron. Le conflit intérieur. Arles: Éditions Photosynthèse, 2013.

PROENÇA, Caio; MONTEIRO, Charles. O fotojornalismo em revista: o trabalho do fotógrafo e do editor de fotografia em Veja (1977). Maracanan, UERJ, v. 12, n. 14, p. 190209, 2016.

RITCHIN, Fred. Close witnesses. The involvement of the photojournalism. In: FRIZOT, Michel (Ed.). A new history of photography. Köln: Könemann, 1988. p. 591-611.

ROUILLÉ, André. A fotografia entre documento e arte contemporânea. São Paulo: SENAC, 2009.

SOULAGES, François. Estética da Fotografia: perda e permanência. São Paulo: Editora SENAC São Paulo, 2010.

SOUSA, Jorge Pedro. Uma história crítica do fotojornalismo ocidental. Chapecó: Argos; Florianópolis: Letras Contemporâneas, $2004 a$.

SOUSA, Jorge Pedro. Fotojornalismo: introdução à história, às técnicas e à linguagem da fotografia na imprensa. Florianópolis: Letras Contemporâneas, 2004b.

SOUSA JÚNIOR, Luciano Gomes. Engajamento político e prática fotográfica no Brasil dos anos 1970 e 1980. 2014, 140 f. Dissertação (Mestrado em História) - Universidade Federal 
Fluminense, Instituto de Ciências Humanas e Filosofia, Programa de Pós-Graduação em História, Rio de Janeiro, ., 2014.

STALLABRAS, Julian. Sebastião Salgado and fine art photojournalism. New Left Review, I/223, May-June 1997. Disponível em: <http://newleftreview.org/l/223/julian-stallabrasssebastiao-salgado-and-fine-art-photojournalism>. Acesso em 17/6/2015.

TAVARES, Frederico de Mello Brandão; VAZ, Paulo Bernardo Ferreira. Fotografia jornalística e mídia impressa: forma de apreensão. Revista Famecos, Porto Alegre, n. 27, p. 125-138, 2005.

TEIXEIRA, Evandro. Fotojornalismo. Rio de Janeiro: Editora JB, 1982.

VILCHES, Lorenzo. La lectura de la imagen: prensa, cine, televisión. 6. reimpr. Barcelona: Paidós, 1997 a.

VILCHES, Lorenzo. Teoría de la imagen periodística. 2. reimpr. Barcelona: Paidós, 1997b. 